\title{
Morphological And Topographical Anatomy of Nutrient Foramina In Human Upper Limb Long Bones And Their Surgical Importance
}

\author{
Dr.Meenakshi Parthasarathy(1), Dr.Sharmadhakl(2), Dr.Pushpalatha.M(3), \\ Dr.Parthasarathy Kr (4), Dr Krishnarjun P (5), Dr Reddy Priyatham Tulasi (6) \\ ${ }^{1}$ Associate Professor, Department Ofanatomy, Bangalore Medical College \& Research Institute, Bangalore, \\ Karnataka \\ ${ }^{2,3}$ Department Ofanatomy, Bangalore Medical College \& Research Institute, Bangalore, Karnataka \\ ${ }^{4}$ Professor And Hod, Department Of Radiology, S S Institute Of Medical Sciences \& Research Center, \\ Davangere, Karnataka \\ ${ }^{5,6}$ Department Of Radiology, S S Institute Of Medical Sciences \& Research Center, Davangere, Karnataka
}

\begin{abstract}
:
Objectives: To study the morphology and topography of nutrient foramina and to determine the foraminal index of the upper limb longbones.

Materials and Methods: The study comprised of 243 upper limb long bones, which included humeri, radii, and ulnae. The nutrientforamina were identified macroscopically in all the bones and an elastic rubber band was applied around these foramina. The bones werephotographed with the digital camera and foramen index was calculated. Each bone was divided into five equal parts and was analyzedtopographically.

Results: From our observations, 93.8\% of the humeri had single nutrient foramen. The double foramen was observed in $3.1 \%$ of the cases and the foramen was found absent in 3.1\% of the humeri. In case of radius, $94.4 \%$ had single foramen, $1.4 \%$ haddouble foramen, and in $4.2 \%$ of the cases, it was absent. With respect to ulna, all the 75 bones had single foramen. The mean foraminalindex was 57.6 for the humerus, 34.4 for both the ulna and radius. The majority (70\%) of the foramina in humerus were located at the $3 / 5^{\text {th }}$ part, $83.6 \%$ of the ulnae foramina at the 2/5th part and $87.7 \%$ of the radii foramina at the 2/5th part.

Conclusions: The study has providedadditional information on the morphology and topography of nutrient foramina in upper limb long bones. The knowledge about theseforamina is useful in certain surgical procedures to preserve the circulation. As microvascular bone transfer is becoming more popular, a convention for the anatomical description of these foramina is important.
\end{abstract}

Keywords: foraminal index, long bones, morphology, nutrient artery, nutrient foramen, topography.

\section{Introduction}

The long bone is supplied by a nutrient artery, whichenters the bone obliquely through the nutrient foramen,which is directed away, as a rule, from the growing end[1]. It is well known that they seek the elbow and fleefrom the knee [2]. This is because one end of limb bonegrows faster than the other do. Henderson RG [3]reported that their position in mammalian bones are

variable and may alter during the growth. Thetopographical knowledge of these foramina is useful incertain operative procedures to preserve the circulation[4-6]. It is important that the arterial supply bepreserved in the free vascularized bone grafts, so that theosteocytes and osteoblasts can survive [7]. When a bone graft is taken, the vascularizationof the remaining bones has to be considered. Thevascularity of this area allows various options ingrafting [8]. It was reported that the ideal bone graft forthe free transfer should include endosteal and periostealblood supply with good anastomosis [5]. The bonydefect, which is left behind following traumatic injuries,tumor resection procedures, pseudoarthrosis all havebeen reconstructed by bone grafting procedures and thepreferred modality is free vascularized bone graft [9].

The importance of preoperative angiography remainsimportant to exclude the possible vascular anomalies inboth recipient and donor bones for the microvascularbone transfers [10]. Though there are few reportsavailable on the morphology of nutrient foramina of thelower limbs $[6,10,11]$, the upper limb foramina wererarely studied. The aim of the present investigation was to study the topographic anatomy and morphology ofthe nutrient foramina in human adult upper limb longbones. The foraminal indexes for the upper limb longbones were also determined. 


\section{Materials and Methods}

The study included 243 upper limb long boneswhich included 96 humeri (41 right side and 55 leftside), 72 radii (41 right side and 31 left side) and 75ulnae (31 right and $44 \mathrm{left}$ ). The bones (Figure 1) wereobtained from the osteology section of our department.The age and sex of the bones were not determined.There exists an agreement from the Bangalore medical college Ethics Committee where the present study wasperformed. The bones, which had gross pathologicaldeformities, were excluded from the study. All thebones were macroscopically observed for the number,location and direction of the nutrient foramina.A magnifying lens was used to observe the foramina.The nutrient foramina (Figure 2) were identified bythe presence of a well-marked groove leading to themand by a well-marked, often slightly raised, edge at thecommencement of the canal. Only diaphysial nutrientforamina were observed in all the bones (Figure 2), a 24-gauge needle was passed through each foramen toconfirm their patency.

The number and topography of the foramina inrelation to specific borders or surfaces of the diaphysiswere analyzed. The foramina within $1 \mathrm{~mm}$ from anyborder were taken to be lying on that border. An elasticrubber band was applied around these foramina(Figure 1) and photographs were taken with the digitalcamera. The measurements of the bones were doneover the photographs. The foramen index (F.I.) wascalculated by applying the Hughes $\mathrm{H}$ [12] formula,dividing the distance of the foramen from the proximalend (D) by the total length of the bone (L) which wasmultiplied by hundred: F.I $=\mathrm{D} / \mathrm{L} \times 100$

The F.I. was determined for all the bones whichgive the location of the nutrient foramen, each bonewas divided into five equal parts and was analyzedtopographically. The data were collected on astandardized sheet and tabulated. Few of the bones wereradiographed in order to look for the radiologicalappearance of the nutrient foramina. The films weretaken using the diagnostic X-ray imaging system. The radiographic tubes were operated at approximately60 kiloVolt peak $(\mathrm{kVp})$ and 10 milliAmpere second $(\mathrm{mAs})$ at a $100 \mathrm{~cm}$ source to image receptor distance(SID).

\section{Results}

In the present study, $93.8 \%$ of the humeri had asingle nutrient foramen. The double foramen was observed in $3.1 \%$ of the cases and the foramen wasfound absent in $3.1 \%$ of the humeri. Fifty-eight humerishowed the foramina at the antero-medial surface(AMS), 32 at the medial surface (MS), three each at theanterior border and posterior surface. The morphologicaland topographical distribution of the foramina ofhumerus is represented in Table 1.

Table 1 Morphological and topographical distributionof the nutrient foramina in the humerus $(\mathrm{n}=96)$

\begin{tabular}{|l|l|l|l|l|l|l|l|l|}
\hline $\begin{array}{l}\text { No.of } \\
\text { foramina }\end{array}$ & $\begin{array}{l}\text { Right } \\
\text { side }\end{array}$ & $\begin{array}{l}\text { Left } \\
\text { side }\end{array}$ & Total & \% & AB & MB & AMS & PS \\
\hline 0 & 1 & 2 & 3 & 3.1 & - & - & - & - \\
\hline 1 & 39 & 51 & 90 & 93.8 & 2 & 31 & 54 & 3 \\
\hline 2 & 1 & 2 & 3 & 3.1 & 1 & 1 & 4 & - \\
\hline Total & 41 & 55 & 96 & 100 & 3 & 32 & 58 & 3 \\
\hline
\end{tabular}

$\mathrm{AB}$ - anterior border; MB - medial border; AMS - anteromedialsurface; PS - posterior surface.

In case of radius, $94.4 \%$ had single foramen, $1.4 \%$ had double foramen, and in $4.2 \%$ of the cases theforamen was absent. The foramen was present at theanterior surface (AS) in 52 radii, at the interosseousborder (IB) in 10 bones, at the anterior border (AB) infour bones and at the posterior surface (PS) in fourbones. The analyzes of the distribution of the radialnutrient foramen is shown in Table 2 .

Table 2 - Morphological and topographical distributionof the nutrient foramina in the radius $(\mathrm{n}=72)$

\begin{tabular}{|l|l|l|l|l|l|l|l|l|}
\hline $\begin{array}{l}\text { No.of } \\
\text { foramina }\end{array}$ & $\begin{array}{l}\text { Right } \\
\text { side }\end{array}$ & $\begin{array}{l}\text { Left } \\
\text { side }\end{array}$ & Total & $\mathbf{\%}$ & AB & MB & AMS & PS \\
\hline 0 & 3 & - & 3 & 4.2 & - & - & - & - \\
\hline 1 & 37 & 31 & 68 & 94.4 & 9 & 4 & 51 & 4 \\
\hline 2 & 1 & -1 & 1 & 1.4 & 1 & - & 1 & - \\
\hline Total & 41 & 31 & 72 & 100 & 10 & 4 & 52 & 4 \\
\hline
\end{tabular}

IB - interosseous border; AB - anterior border; AS - anteriorsurface; PS - posterior surface.

With respect to ulna, all the 75 bones had singleforamen. It was seen at the anterior surface in 65 cases,anterior border in eight cases and at the interosseousborder in two cases. The distribution is represented inTable 3. 
Morphological And Topographical Anatomy Of Nutrient Foramina In Human Upper ...

Table 3 - Morphological and topographical distributionof the nutrient foramina in the ulna $(n=75)$

\begin{tabular}{|l|l|l|l|l|}
\hline ulna & No. & IB & AB & AS \\
\hline Right side & 31 & 2 & 4 & 25 \\
\hline Left side & 44 & - & 4 & 40 \\
\hline total & 75 & 2 & 8 & 65 \\
\hline
\end{tabular}

IB - interosseous border; $\mathrm{AB}$ - anterior border; AS - anteriorsurface.

The mean foraminal index was 57.6 for the humerus,34.4 for both the ulna and radius. The majority (70\%) ofthe foramina in humerus were located at the $3 / 5$ th part,83.6\% of the ulnae foramina at the $2 / 5$ th part and $87.7 \%$ of the radii foramina at the $2 / 5$ th part. Table 4 analyzes

the topography of the foramina along the length of thebones, i.e. in the $1 / 5$ th, $2 / 5$ th, $3 / 5$ th, $4 / 5$ th and $5 / 5$ th parts asseen from the foraminal index.

Table 4-Topographical distribution of the nutrientforamina based on the foraminal index of the upperlimb long bones $(n=243)$

\begin{tabular}{|l|l|l|l|}
\hline Topography & Humerus & Ulna & Radius \\
\hline $1 / 5^{\text {th }}$ part & nil & Nil & nil \\
\hline $2 / 5^{\text {th }}$ par & nil & $83.6 \%$ & $87.7 \%$ \\
\hline $3 / 5^{\text {th }}$ part & $70 \%$ & $16.4 \%$ & $12.3 \%$ \\
\hline $4 / 5^{\text {th }}$ part & $30 \%$ & Nil & Nil \\
\hline $5 / 5^{\text {th }}$ part & Nil & Nil & Nil \\
\hline mean F.I & 57.6 & 34.4 & 34.4 \\
\hline
\end{tabular}

The radiographic appearance of the nutrient foraminaof the humerus, radius and ulna (arrow marks) areshown in Figure 3.

\section{Discussion}

The external opening of the nutrient canal, usuallyreferred to as the nutrient foramen, has a particularposition for each bone [13]. Longia GS et al. [14]observed that the position of nutrient foramina was onthe flexor aspect in their human long bone specimens.It is generally agreed that the vessels which occupy thenutrient foramen are derived from those that took part inthe initial invasion of the ossifying cartilage, so that thenutrient foramen was at the site of original centre ofossification [13]. Hughes $H$ [12] observed that variantforamina are common in the femur, rare in the radiusand very rare in other bones. Variations in the directionof nutrient foramina have been observed in manytetrapods and there is some similarity in the foraminalpattern in mammals and birds [12]. Schwalbe G [15] explained that growth at the two ends of a long bone

before the appearance of the epiphyses is equal. Hence,the nutrient foramen before the birth should be directedhorizontally. Many theories have been put forward toaccount for the direction of the foramina and also theanomalously directed ones. Among them, the 'periostealslip' theory of Schwalbe [15] and the vascular theory ofHughes [12] are widely accepted in the literature.

Longia GS et al. [14] stated that the vascular theoryoffers the best explanation of all reported anomaliesas well as the normal fashioning of nutrient canals.Patake SM and Mysorekar VR [2] opined that thenumber of foramina does not seem to have anysignificant relation to the length of the bone. Theydescribed that the number of foramina may not haverelation to the number of ossification centers, becausethe femur, which is having one primary centre, usuallyhas two foramina and clavicle, with two primarycenters, has generally a single foramen. It was suggestedthat the direction of nutrient foramina is determined bygrowing end of the bone. The growing end is supposedto grow at least twice as fast as the other end [4].

The well-known factors, which may affect nutrientforamen position, are the growth rates at the two ends ofthe shaft and bone remodeling [3]. Lacroix $\mathrm{P}$ [16] suggested that the pull of muscle attachments onperiosteum explained certain anomalous nutrientforamina directions. Nutrient arteries, which are themain blood supply to long bones, are particularly vitalduring the active growth period and at the early phasesof ossification [17]. These nutrient arteries pass throughthe nutrient foramina, the position of nutrient foraminain mammalian bones are variable and may alter duringthe growth [3]. In humerus, the nutrient artery usuallyarises either from the brachial artery or from theprofundabrachii artery as one or more branches or fromthe muscular branches of these arteries. The doubleforamina in humerus would suggest that one of themwould be the main foramen and the other accessory oneand hence the nutrient artery can arise either from thebrachial or profundabrachii artery [4]. Menck $\mathbf{J}$ et al. [8] reported that the inner part of humerus is usuallysupplied by just one nutrient artery entering the nutrientforamen just below its middle part. In radius the arteryarises from the anterior or posterior interosseous artery,this explains the foramina on its posterior surface. Theulna gets its nutrient artery from the ulnar artery or anyof its muscular branches. In both radius and ulna, themain branch of 
the nutrient artery has an ascendingcourse. The anterior interosseous artery, as the mainartery of periosteal and endosteal supply of humanulna and radius, is important in transplantation andreconstruction, especially with a view to reduce the rateof pseudarthrosis [18]. The nutrient arteries of the ulnaand radius enter the bones in the second proximalquarter of diaphysis, at the radius from anterior tomedial, at the ulna from anterior to anterolateral [19].

The available reports on the upper limb bonenutrient foramina include the study on nutrient foraminaof the metacarpals and metatarsals by Singh I [20, 21],Patake SM and Mysorekar VR [2], on the radius and ulnaby Shulman SS [22]. Mysorekar VR and Nandedkar AN[1] studied the nutrient foramina in the phalanges. ForriolCampos F et al. [23] studied the nutrient foramina of bothupper and lower limbs. According to Mysorekar VR [4], humerus usually has two nutrient foramina and theyoccur just below the middle part of the bone or in theradial groove or frequently in both these locations. However, we observed the double nutrient foramina ofthe humerus in only $3.1 \%$ of the cases. The radius andulna usually have a single nutrient foramen [4]. In thepresent study, all the ulnae had single nutrient foramina,but we observed the double nutrient foramina of theradius in $1.4 \%$ of the cases. The radius has its forameninvariably above the middle part, whereas in the ulna,the foramen will be in the middle third. In both radiusand ulna, the foramen most frequently occurs on theanterior surface nearer to anterior or interosseous border[4]. In the present study, $86.7 \%$ of the ulna and $72.2 \%$ of the radius had the foramen at the anterior surface. The absence of nutrient foramina in the long bones iswell known [4, 24]. In the present study, 3.1\% of thehumeri and $4.2 \%$ of the radii showed the absence of thenutrient foramina. It was reported that in case thenutrient foramen is absent, the bone is likely to besupplied by periosteal arteries [2].

According to the study from Kizilkanat E et al. [17],the foramina were located on the diaphysis 15$69 \%$ ofthe overall length of the humerus, $22-46 \%$ for the radiusand $27-54 \%$ for the ulna. In contrast, Forriol Campos Fet al. [23] reported that the diaphysial nutrient foraminain the humerus are located at between 50 and $65 \%$ ofthe total length and in the radius and ulna at between 25 and $50 \%$. In the present study, we observed that thenutrient foramina were present between $43-66 \%$ of thelength of the humerus, $26-46 \%$ of the length of radiusand $25-58 \%$ of the length of ulna. These findings weresimilar to the reports of Kizilkanat E et al. [17] andForriol Campos F et al. [23].

Nagel A [25] described the risks for intraoperativeinjury to the nutrient artery during its exposure. He hasalso offered some suggestions for placing the internalfixation devices with minimal injury to it. It wasdescribed that the knowledge about these foramina isuseful in the surgical procedures to preserve thecirculation. The findings are important for the clinicianswho are involved in bone graft surgical proceduresand are enlightening to the clinical anatomists andmorphologists.

\section{Conclusions}

The present study has provided additionalinformation on the foraminal index, morphology andtopography of the nutrient foramina in upper limblong bones. The anatomical data of this subject isenlightening to the clinician as the microvascular bonetransfer is becoming more popular.

\section{Acknowledgements}

We gratefully acknowledge all the non-teachingstaff members of our department for their help andcooperation.

\section{References}

[1]. Mysorekar VR, Nandedkar AN, Diaphysial nutrient foraminain human phalanges, J Anat, 1979, 128(Pt 2):315-322.

[2]. Patake SM, Mysorekar VR, Diaphysial nutrient foraminain human metacarpals and metatarsals, J Anat, 1977,124(Pt 2):299-304.

[3]. Henderson RG, The position of the nutrient foramen inthe growing tibia and femur of the rat, J Anat, 1978,125(Pt 3):593-599.

[4]. Mysorekar VR, Diaphysial nutrient foramina in human longbones, J Anat, 1967, 101(Pt 4):813-822.

[5]. Taylor GI, Fibular transplantation. In: Serafin D, Bunke HJ(eds), Microsurgical composite tissue transplantation, C.V.Mosby Co., St. Louis, 1979, 418-423.

[6]. McKee NH, Haw P, Vettese T, Anatomic study of thenutrient foramen in the shaft of the fibula, ClinOrthopRelatRes, 1984, 184:141-144.

[7]. Green DP (ed), Operative hand surgery, 2nd edition, ChurchillLivingstone, New York, 1988, 1248

[8]. Menck J, Döbler A, Döhler JR, Vaskularisation desHumerus, Langenbeck's Arch Surg, 1997, 382(3):123-127.

[9]. Pho RWH, Microsurgical technique in orthopaedics, 1stedition, Butterworth \& Co. Ltd., Scotland, $1988,128$.

[10]. Gümüsburun E, Yücel F, Ozkan Y, Akgün Z, A study of thenutrient foramina of lower limb long bones, Surg RadiolAnat, 1994, 16(4):409-412.

[11]. Collipal E, Vargas R, Parra X, Silva H, Del Sol M,Diaphyseal nutrient foramina in the femur, tibia and fibulabones, Int J Morphol, 2007, 25(2):305-308.

[12]. Hughes $\mathrm{H}$, The factors determining the direction of thecanal for the nutrient artery in the long bones of mammalsand birds, ActaAnat (Basel), 1952, 15(3):261-280.

[13]. Payton CG, The position of the nutrient foramen anddirection of the nutrient canal in the long bones of themadder-fed pig, $\mathrm{J}$ Anat, 1934, 68(Pt 4):500-510.

[14]. Longia GS, Ajmani ML, Saxena SK, Thomas RJ, Study ofdiaphyseal nutrient foramina in human long bones, ActaAnat (Basel), 1980, 107(4):399-406 
[15]. Schwalbe G, ZeitschriftfürAnatomie und Entwicklungsgeschichte, 1876, 1:307-352.

[16]. Lacroix P, The organization of bones, J. \& A. Churchill Ltd.,London, 1951.

[17]. Kizilkanat E, Boyan N, Ozsahin ET, Soames R, Oguz O,Location, number and clinical significance of nutrientforamina in human long bones, Ann Anat, 2007, 189(1):87-95.

[18]. Menck J, Schreiber HW, Hertz T, Bürgel N, Angioarchitekturvon Ulna und Radius und ihrepraktischeRelevanz,Langenbeck's Arch Surg, 1994, 379(2):70-75.

[19]. Giebel GD, Meyer Ch, Koebke J, Giebel G, Arterial supplyof forearm bones and its importance for the operativetreatment of fractures, Surg RadiolAnat, 1997, 19(3):149-153.

[20]. Singh I, Variations in the metacarpal bones, J Anat, 1959,93(2):262-267.

[21]. Singh I, Variations in the metatarsal bones, J Anat, 1960,94(Pt 3):345-350.

[22]. Shulman SS, Observations on the nutrient foramina of thehuman radius and ulna, Anat Rec, 1959, 134:685-697.

[23]. Forriol Campos F, Gomez Pellico L, Gianonatti Alias M,Fernandez-Valencia R, A study of the nutrient foramina inhuman long bones, Surg RadiolAnat, 1987, 9(3):251-255.

[24]. Lutken $P$, Investigation into the position of the nutrientforamina and the direction of the vessel canals in the shaftsof the humerus and femur in man, ActaAnat (Basel), 1950,(1-2):57 68.

[25]. Nagel A, The clinical significance of the nutrient artery,Orthop Rev, 1993, 22(5):557-561.

Figure 1 - Upper limb longbones (A - humeri; B -radii; $\mathrm{C}$ - ulnae): the rubberbands were tied at theforamina.

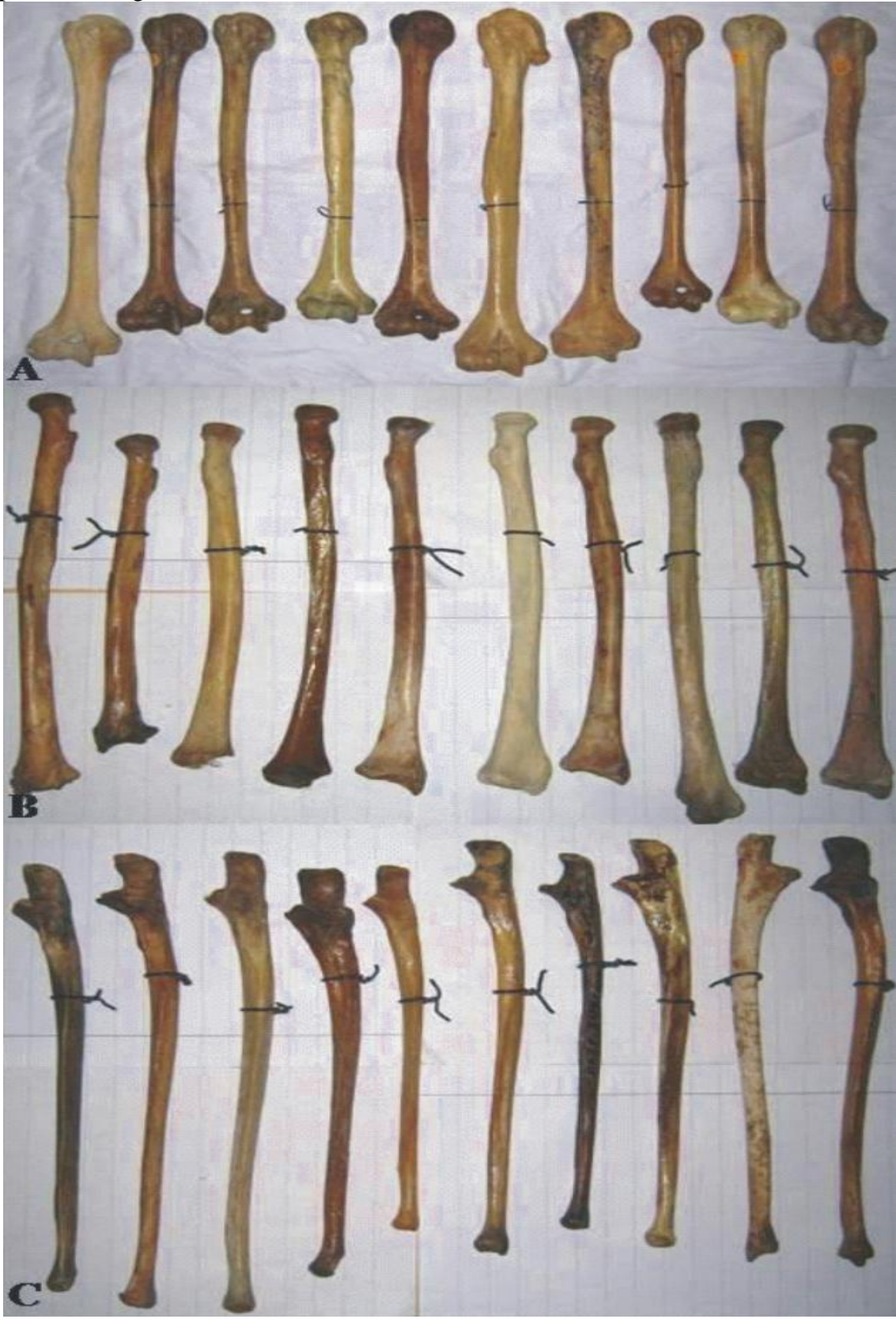

Figure 2 - The humerus (A),radius $(B)$ and ulna $(\mathrm{C})$ bonesshowing the nutrient foramina (arrow mark), which are directedtowards the elbow joint. 


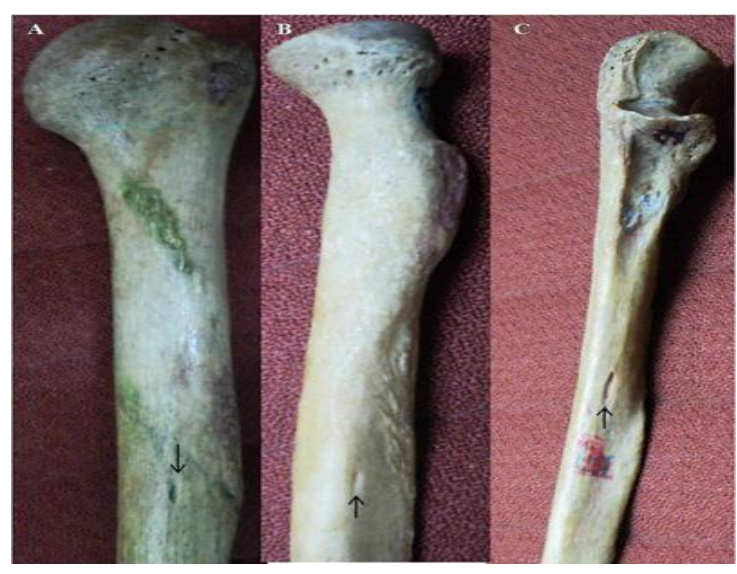

Figure 3 - The radiographicfilm showing the upper limblong bones and their nutrientforamina (arrow mark).

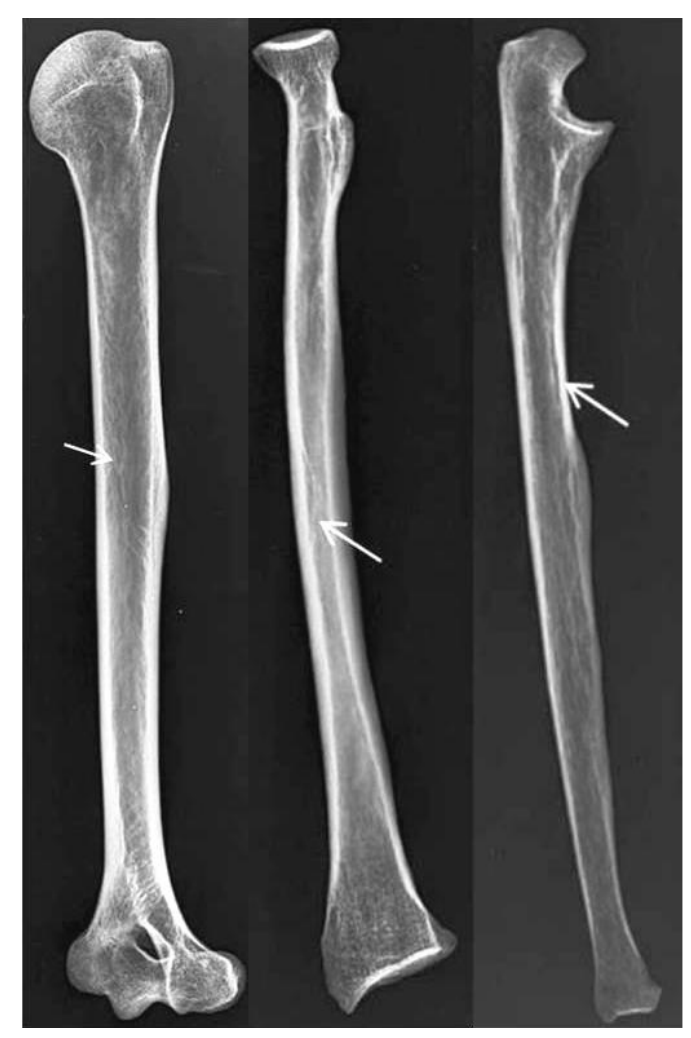

